\title{
KRITIKUS ÁSVÁNYOK ÉS ELEMEK A SZENDRŐI FILLIT FORMÁCIÓBAN (SZENDRŐI-HEGYSÉG, ÉK-MAGYARORSZÁG)
}

\author{
Leskóné Majoros Lívia \\ PhD hallgató, Miskolci Egyetem, Ásványtani-Földtani Intézet \\ 3515 Miskolc, Miskolc-Egyetemváros, e-mail: asklivia@uni-miskolc.hu \\ Leskó Máté Zsigmond \\ tudományos segédmunkatárs, Miskolci Egyetem, Ásványtani-Földtani Intézet \\ 3515 Miskolc, Miskolc-Egyetemváros, e-mail: askmate@uni-miskolc.hu

\section{Szakáll Sándor} \\ egyetemi tanár, Miskolci Egyetem, Ásványtani-Földtani Intézet \\ 3515 Miskolc, Miskolc-Egyetemváros, e-mail: askszs@uni-miskolc.hu \\ Kristály Ferenc \\ tudományos fömunkatárs, Miskolci Egyetem, Ásványtani-Földtani Intézet \\ 3515 Miskolc, Miskolc-Egyetemváros, e-mail: askkf@uni-miskolc.hu
}

\begin{abstract}
Absztrakt
Tanulmányunk célja a Szendröi-hegységben található Meszes település melletti Vasbánya-hegy felszini feltárásaiból (Szendrői Fillit Formáció) gyüjtött fekete fillitek vizsgálata optikai és elektronmikroszkópiával, illetve röntgen-pordiffrakcióval a közetekben található grafitra és kritikus elemekre fókuszálva. Vizsgálataink alapján a grafit pikkelyes formában, 50-150 $\mu$ m-es nagyságban volt észlelhetö. A kritikus elemeket tekintve, a minták tartalmaztak titánt (föként TiO $O_{2}-k e ́ n t$, ritkán ilmenitként, valamint fengitbe beépülve), nióbiumot (TiO $\mathrm{O}_{2}$-ba beépülve), stronciumot (fluorapatitban és monacitban), valamint ritkaföldfémeket (xenotimban, monacitban és goethitben).
\end{abstract}

Kulcsszavak: kritikus elemek, kritikus nyersanyagok, grafit, ritkaföldfémek

\begin{abstract}
In our study, black phyllites collected from outcrops of Vasbánya-hill (near Meszes village, Szendrö Mts, Szendrö Phyllite Formation) are examined with optical and electron microscopy and with X-ray powder diffraction focusing on the graphite and critical element content of the rocks. Based on our results, graphite was detected as 50-150 $\mu \mathrm{m}$ sized flakes. Regarding the critical elements, the samples contained titanium (mainly as $\mathrm{TiO}_{2}$, rarely as ilmenite, and built into phengite), niobium (built into $\mathrm{TiO}_{2}$ ), strontium (in fluorapatite and monazite), and rare earth elements (in xenotime, monazite and goethite).
\end{abstract}

Keywords: critical elements, critical raw materials, graphite, rare earth elements

\section{Bevezetés}

Az Európai Bizottság 2020-ban adta ki legfrissebb jelentését az Európai Unió kritikus nyersanyag listájáról [1], amelyen jelenleg már 30 nyersanyag szerepel (1. táblázat). A listán szereplő természetes grafit mellett, a szerves anyaghoz való geokémiai affinitásuknak köszönhetően, számos elem dúsulása 
ismert [2;3], ráadásul ezen elemek közül néhány szintén szerepel a 2020-as kritikus nyersanyagok listáján.

Tanulmányunk fókuszában ezen kritikus nyersanyagok és elemek állnak, vagyis a grafit és a grafitosodáshoz potenciálisan kötődő elemek: a vanádium, titán, stroncium, nióbium, valamint a könnyü és a nehéz ritkaföldfémek (röviden RFF-ek).

1. táblázat. Az Európai Unió 2020-as kritikus nyersanyag listája [1]. Kiemelve a jelen tanulmányban érintett kritikus elemek

\begin{tabular}{|c|c|c|c|c|}
\hline \multicolumn{5}{|c|}{ Kritikus nyersanyag lista (2020) } \\
\hline Antimon & Kobalt & Nehéz RFF-ek & Természetes gumi & Fém-szilícium \\
\hline Barit & Kokszolható szén & Indium & Nióbium & Tantál \\
\hline Bauxit & Fluorit & Lítium & Platinafémek & Titán \\
\hline Berillium & Gallium & Könnyú RFF-ek & Foszfátos kőzetek & Vanádium \\
\hline Bizmut & Germánium & Magnézium & Foszfor & Volfrám \\
\hline Borátok & Hafnium & Természetes grafit & Szkandium & Stroncium \\
\hline
\end{tabular}

A terepbejárás és mintagyüjtés a Szendrői-hegységben található, Meszes település mellett lévő Vasbánya-hegy felszíni feltárásaiból történt (1. ábra) (Szendrői Fillit Formáció: karbon korú, fokozatosan mélyülő medencebeli kifejlődési fácies jellemzi $[4 ; 5])$. Az onnan származó fekete filliteket vizsgáltuk meg polarizációs ércmikroszkópos, pásztázó elektronmikroszkópos (SEM-EDS) és röntgen-pordiffrakciós (XRD) vizsgálati módszerekkel.

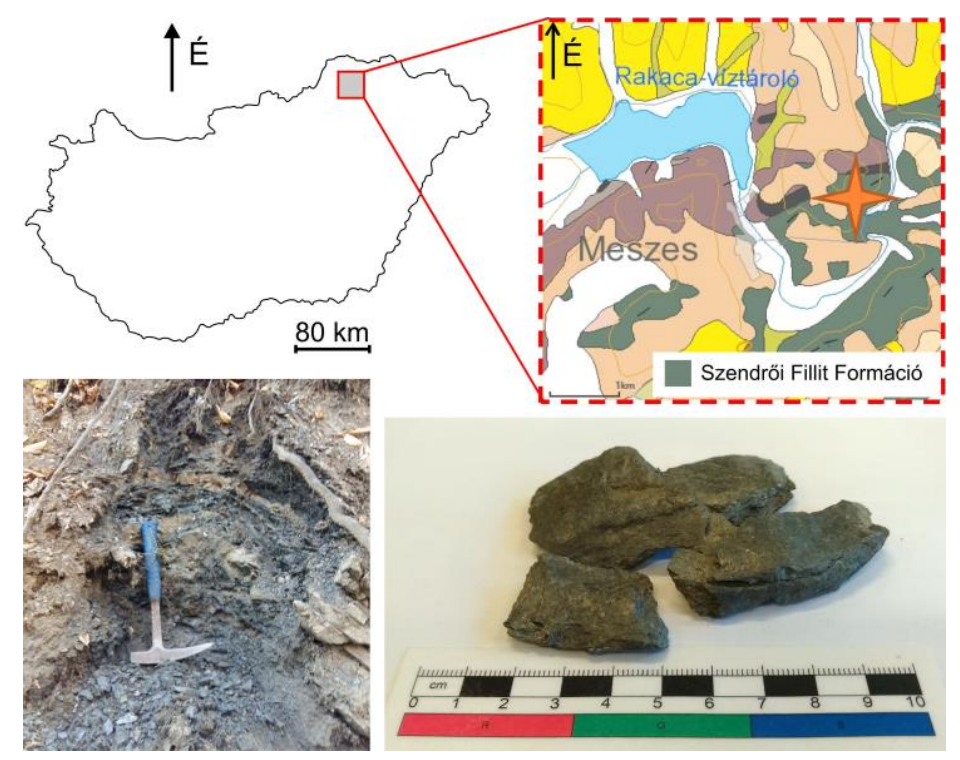

1. ábra. A vizsgált terület sematikus földtani térképe [6], csillaggal jelölve a feltárások helyét (fent). Lent balra - az egyik feltárásról kép, lent jobbra - kép a begyüjtött mintákról 


\section{Vizsgálati módszerek}

A terepbejárás során gyüjtött mintákból a mikroszkópos vizsgálatokhoz polírozott felületű csiszolatok készültek. Az optikai mikroszkópia Zeiss AxioCam MRc5 kamerával ellátott Zeiss Imager.A2m AXIO polarizációs ércmikroszkópon történt. A pásztázó elektronmikroszkópos (SEM-EDS) vizsgálatokat pedig egyrészt JEOL JXA-8600 Superprobe elektronmikroszkópon (20 kV gyorsító feszültség, 20 nA mintaáram, 60 s időtartamú EDS mérések), másrészt ThermoFisher Helios G4 PFIB CXe müszeren (20 kV gyorsító feszültség, $3.2 \mathrm{nA}$ mintaáram, $50 \mathrm{~s}$ időtartamú EDS mérések) végeztük el.

A mintákból készített porpreparátumokon röntgen-pordiffrakciós (XRD) vizsgálatok történtek (Bruker D8 Advance múszer, $\mathrm{Cu} \mathrm{K}$-alfa sugárzás, $40 \mathrm{kV}, 40 \mathrm{~mA}$, Göbel-tükörrel elöállított párhuzamos nyaláb geometria, Vantec-1 helyzetérzékelő detektor, $1^{\circ}$ ablaknyílás, $0.007^{\circ} 2 \theta / 24 \mathrm{sec}$ ). A kiértékelés DiffracPlus EVA szoftverben, Search/Match algoritmussal, az ICDD PDF2 2005 adatbázisa alapján történt.

\section{Eredmények}

\subsection{Mikroszkópia}

Az optikai és pásztázó elektronmikroszkópos megfigyelések alapján megállapítható, hogy a minták szövete erősen irányított, foliált, amelyben nyírási zónára jellemző deformációs elemek voltak megfigyelhetők, például krenulációs palásság, mikroredőzöttség, kalcit kristályok deformációs ikresedése, nyomásárnyék rutil szemcsék körül, valamint grafit kristályok unduláló kioltása.

A meszesi minták mátrixát 20-50 $\mu \mathrm{m}$-es nagyságú kvarc szemcsék és filloszilikát lemezek (klorit, muszkovit, fengit) alkották. A kvarc gyakran unduláló kioltással jelent meg, a fengitben pedig gyakran kevés Ti-tartalom is jelentkezett az EDS mérések során. A klorit pikkelyekben az EDS mérések alapján nagyobb a Fe-tartalom, mint a Mg, így a vasgazdag klinoklor típusba sorolható.

A minták számos járulékos ásványt tartalmaztak. Észleléseink alapján a grafit 50-150 $\mu$ m-es pikkelyes formában, irányítottan helyezkedett el a minták szövetében (2. ábra). Az optikai megfigyelések során tökéletes anizotrópiával, erős bireflexióval, pleokroizmussal és unduláló kioltással volt megfigyelhető. Az EDS mérések nem mutattak kéntartalmat a grafitokban.

Ti-tartalmú ásványként föként $\mathrm{TiO}_{2}$-ok voltak észlelhetők a mintákban (rutil és anatáz is azonosítható volt az optikai vizsgálatok során). A $\mathrm{TiO}_{2}$-ok $10-20 \mu \mathrm{m}$-es nagyságú tük formájában jelentek meg, amelyek gyakran 200-400 $\mu$ m-es fészkekbe, halmazokba rendeződtek (3. ábra). Ritkán kevés $\mathrm{Nb}$-tartalmat is lehetett mérni bennük. A $\mathrm{TiO}_{2}$-ok mellett elvétve ilmenit is azonosítható volt a mintákban $\sim 10 \mu \mathrm{m}$-es nagyságban.

RFF-eket tartalmazó ásványként egyrészt azonosítható volt a mintákban xenotim, amely a nehéz RFF-eket, másrészt monacit-(Ce), amely pedig a könnyü RFF-eket tartalmazta (2. táblázat). A xenotim $\sim 20 \mu \mathrm{m}$-es nagyságú szemcsékként fordult elö, néha összenőve a monacittal (4. ábra). A monacit legtöbbször fluorapatit, klorit, illetve $\mathrm{TiO}_{2}$ mellett volt észlelhető, gyakran több száz $\mu \mathrm{m}$-es nagyságú halmazokat alkotva, azonban fluorapatit szegélyi részén is megfigyelhető volt $<10 \mu \mathrm{m}$-es nagyságban. Ezeken kívül még azonosítható volt a mintákban könnyü RFF-eket megkötő goethit is (4. ábra). 

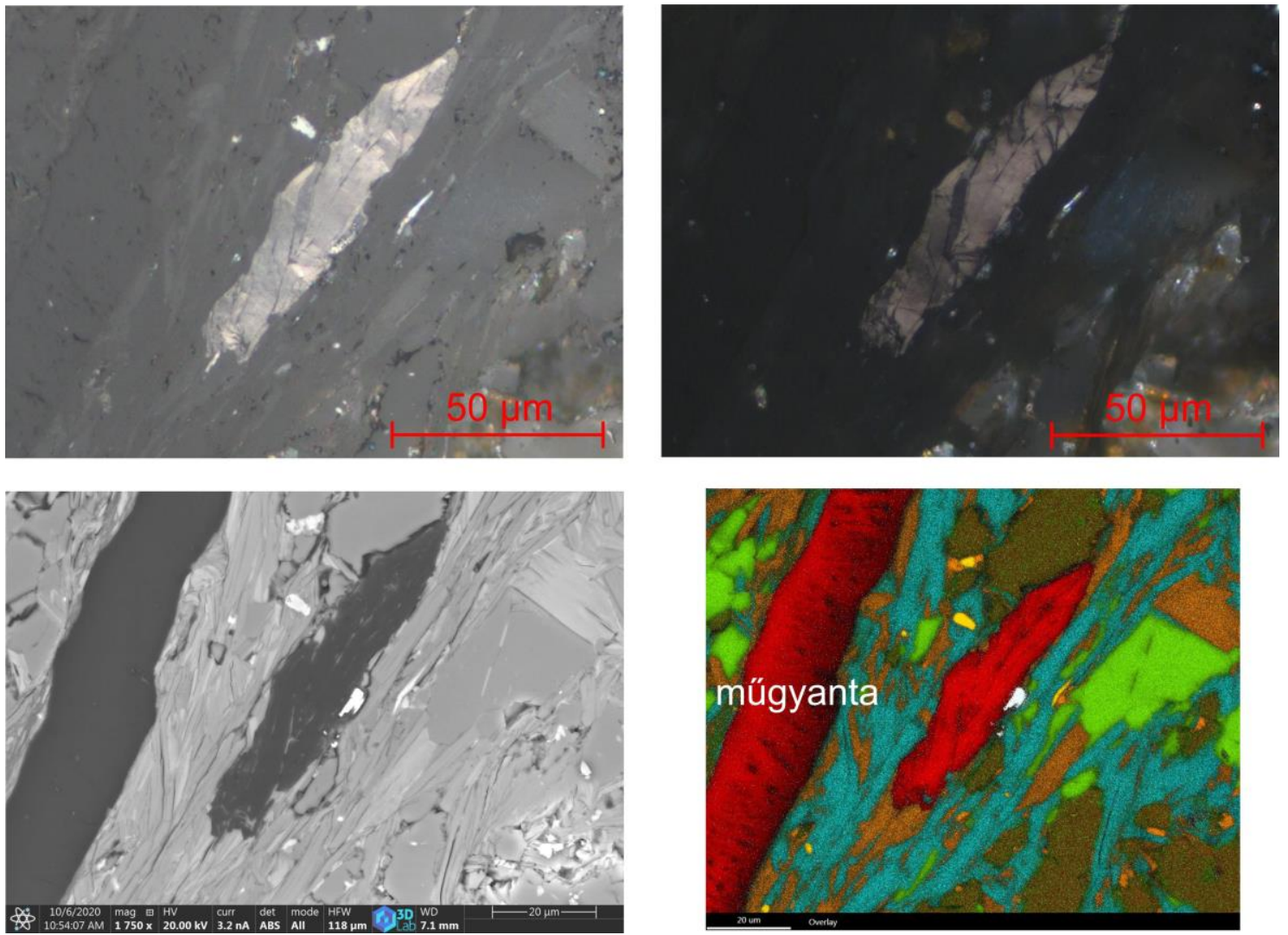

2. ábra. Grafit pikkely az irányitott szövetben. Balra fent-optikai kép, $1 \mathrm{~N}$; jobbra fent-optikai kép, $x N$; balra lent - visszaszórt elektronkép; jobbra lent-elemtérkép (C: piros; Ti: sárga; P: fehér; Fe: narancs; K: kék; Si: zöld; Na: barna)
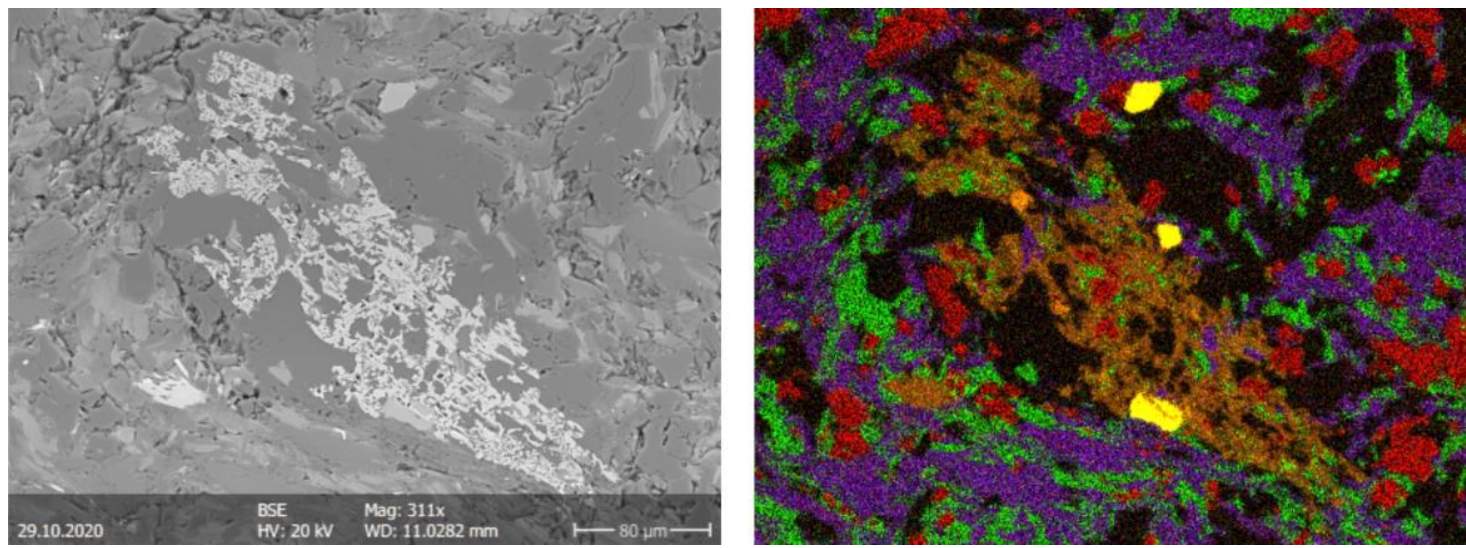

3. ábra. $\mathrm{TiO}_{2}$ halmaz fluorapatit szemcsékkel kvarc és csillám mátrixban. Balra-visszaszórt elektronkép, jobbra -fázistérkép (kvarc: fekete; apatit: sárga; kalcit: narancs; rutil: barna; fengit: lila; klorit: zöld; albit: piros) 
2. táblázat. Monacitok kémiai összetétele (nem standardizált EDS mérés, elemi tömegszázalék.) Az Al,

Si, Ca és Fe a környezetéböl származik

\begin{tabular}{|c|c|c|c|c|c|c|c|}
\hline $\mathbf{O}$ & 28,29 & 28,04 & 28,09 & 27,50 & 31,53 & 29,64 & 31,69 \\
\hline $\mathbf{F}$ & 1,05 & 1,13 & 0,88 & 0,61 & 2,33 & 1,52 & 1,70 \\
\hline $\mathbf{A l}$ & - & 0,25 & - & - & - & - & 0,50 \\
\hline $\mathbf{S i}$ & 0,33 & 0,58 & - & - & 0,60 & - & 3,22 \\
\hline $\mathbf{P}$ & 14,22 & 13,56 & 14,16 & 13,49 & 17,50 & 15,84 & 14,95 \\
\hline $\mathbf{C a}$ & 0,20 & 0,30 & 0,51 & 0,51 & 0,37 & 0,34 & 0,22 \\
\hline $\mathbf{F e}$ & - & - & - & 0,64 & - & 0,65 & 0,69 \\
\hline $\mathbf{S r}$ & - & - & 0,89 & 0,92 & - & 0,90 & 1 \\
\hline $\mathbf{L a}$ & 14,23 & 13,03 & 14,50 & 12,29 & 12,70 & 13,62 & 10,83 \\
\hline $\mathbf{C e}$ & 27,91 & 28,62 & 28,93 & 29,25 & 24,05 & 26,64 & 24,73 \\
\hline $\mathbf{N d}$ & 9,84 & 10,81 & 9,33 & 10,15 & 6,95 & 8,55 & 8,35 \\
\hline $\mathbf{S m}$ & 2,36 & 2,74 & 2,17 & 2,24 & 2,89 & 1,74 & 1,15 \\
\hline $\mathbf{G d}$ & 0,64 & 0,13 & 0,53 & 0,38 & 1,08 & 0,57 & - \\
\hline $\mathbf{T h}$ & 0,93 & 0,82 & - & 2,02 & - & - & 0,98 \\
\hline
\end{tabular}
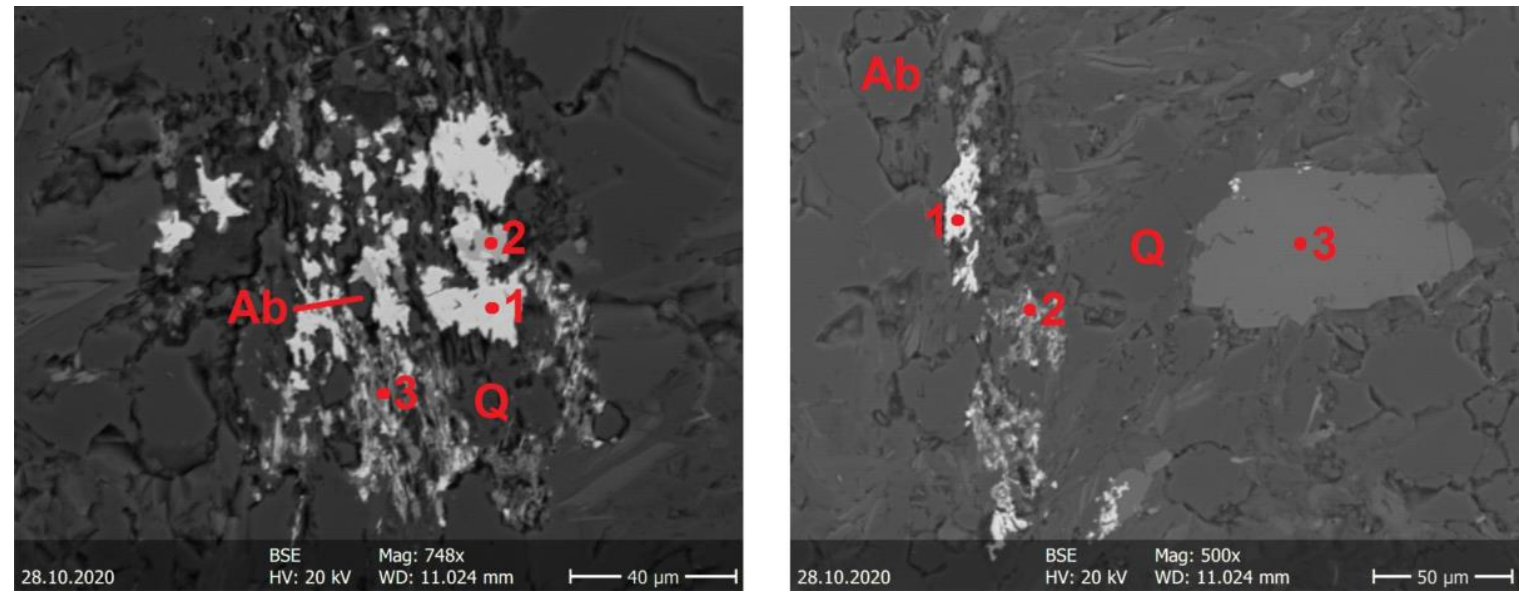

4. ábra. RFF-eket tartalmazó halmazok (fehér) visszaszórt elektronképe albit (Ab) és kvarc (Q) szemcsék között. Balra-monacit (1. mérési pont), xenotim (2. mérési pont) és RFF-eket megkötö goethit (3. mérési pont). Jobbra - monacit (1. mérési pont), RFF-eket megkötö goethit (2. mérési pont) és fluorapatit (3. mérési pont)

A cirkon, mint Zr-ot hordozó ásvány, szintén gyakran megjelent a mintákban, főként 10-30 $\mu$ m-es méretü idiomorf és hipidiomorf szemcsékként. A szilikátok közül megfigyelhető volt még albit, amely a repedésekhez és érhálózatokhoz kötődve bontott szemcsés sávokat alkotott, valamint illit és kaolinit 
is. A járulékos ásványok közül észlelhető volt még kalcit, egyrészt poliszintetikusan ikresedett szemcsékként, másrészt érkitöltőként, harmadrészt pedig fenn-nőtt kristályokként az üregek falán.

\subsection{Röntgen-pordiffrakció}

A röntgen-pordiffrakciós eredmények alapján a mintákban uralkodó mennyiségü volt a kvarc és a muszkovit, mellette a klinoklór, szmektit, albit, rutil, fluorapatit és kalcit reflexiói jelentek meg. A grafitot nem lehetett egyértelmüen beazonosítani a diffraktogramokon kis mennyisége, nanokristályos természete és kitüntetett orientációja miatt, ráadásul a $26^{\circ}-27^{\circ}(2 \theta)$ érték közötti csúcsa $(\mathrm{hkl}=002)$ majdnem átfedésben volt a kvarc $(\mathrm{hkl}=101)$ és $(\mathrm{hkl}=110)$ csúcsaival, így aszimmetrikus csúcsot eredményezett a mérésekben. Az 5. ábra egy reprezentatív minta kiértékelt diffraktogramját mutatja ( $M$-3B fekete azonosítójú minta).

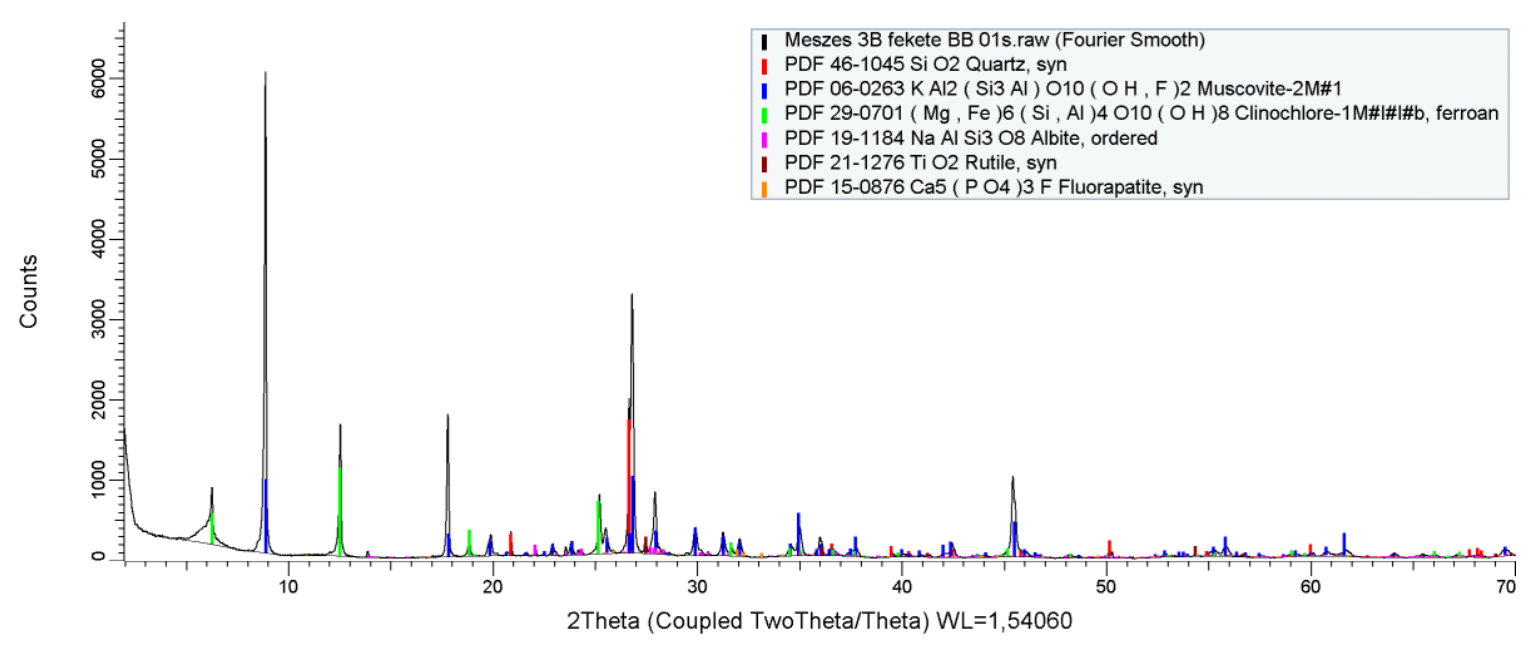

5. ábra. Az M-3B fekete azonositójú reprezentatív minta diffraktogramja

\section{Grafitképződés értelmezése}

A grafitképződés egy progresszív metamorf folyamat [7]. Fizikai feltételeit számos szerző különböző módon becsülte meg: [8] például a grafitképződés kezdetét legalább $300{ }^{\circ} \mathrm{C}$-ra tette, valamint szerinte $450{ }^{\circ} \mathrm{C}$ alatt nem jelenhet meg teljesen rendezett szerkezetü grafit (a nyomás értéke 2-6 kbar közötti). [7] regionális metamorfózis esetén $300-500{ }^{\circ} \mathrm{C}$ és 3 kbar feletti nyomást, kontakt metamorfózisnál $1000{ }^{\circ} \mathrm{C}$ hömérsékletet és $1 \mathrm{kbar}$ nyomást adott meg. [9] szerint a grafitosodás a zöldpala fácies klorit zónájában kezdődik és az amfibolit fácies kezdetéig tart 380-450 ${ }^{\circ} \mathrm{C}$ közötti hőmérsékleten és 2-3 kbar közötti nyomáson. [10] vizsgálatai alapján a rendezetlen szerkezetü grafit zöldpala fáciesben, a rendezett szerkezetü grafit amfibolit fáciesben, míg a makroszkópos kristályméretü grafit (angolul macroplate crystallographic graphite) a granulit fáciesben képződik.

Az általunk vizsgált területen végzett korábbi kutatások alapján $[11 ; 12 ; 13]$ a Szendrői-hegységet kisfokú metamorfózis érte, $300-450{ }^{\circ} \mathrm{C}$ közötti hőmérséklet és 2-3 kbar nyomás, amely a zöldpala metamorf fáciesre jellemzö.

Az észlelt ásványegyüttesben az ilmenit mennyisége a rutilhoz képest számottevően alacsony. Bár a zöldpala fáciesben az ilmenit lenne a domináns ásvány a fázisdiagram alapján [14], ezt [15] úgy magyarázza, hogy egy progresszív metamorfózis során, a kezdetben Ti- és Nb-hordozó ilmenit a 
metamorfózis előrehaladtával bontódni kezd. Az ilmenit helyére polikristályos rutil növekszik, amely szerkezetébe beépül a $\mathrm{Nb}$. Az ilmenit bontódásából felszabaduló Fe-tartalom (és kis mennyiségben a Ti-tartalom is) pedig a környező rétegszilikátokba épül be, kloritot és (Ti-tartalmú) fengitet eredményezve. Ezt az EDS méréseink is alátámasztották. [15] a rutil képződését ilmenitből $\sim 480^{\circ} \mathrm{C}$ hőmérsékletre és 6-9 kbar nyomásra teszi (a zöldpala és amfibolit fácies határára).

A mintákban megfigyelhető monacit és fluorapatit kristályok jelenléte a zöldpala fáciesnél szintén egy nagyobb hőmérsékletü és nyomású képződési eseményre utal [16]. A RFF-ek forrása nem tisztázott, de kicsapódásuk szerkezeti elemekhez kötött és fluidumok jelenlétére utal. A szulfidok hiánya pedig a kőzet és a szerves anyagok alacsony kéntartalmára vezethető vissza.

\section{5. Összefoglalás}

A meszesi minták optikai és elektronmikroszkópos, illetve röntgen-pordiffrakciós vizsgálati eredményei alapján megállapítható, hogy az Európai Unió kritikus nyersanyag listájáról a mintákban található grafit, titán (ilmenitben, $\mathrm{TiO}_{2}$-okban, illetve a fengitekbe beépülve), nióbium $\left(\mathrm{a} \mathrm{TiO}_{2}\right.$-okba beépülve), stroncium (fluorapatitban a Ca-ot helyettesítve, valamint monacitokban), valamint ritkaföldfémek (xenotimban, monacitban és goethitben).

A mikroszkópos megfigyelések szerint a minták szövete metamorf, a kőzeteket nyírási deformáció érte, és a grafit pikkelyek, illetve a kritikus elemeket tartalmazó ásványok föként ezekben a nyírási deformációs zónákban helyezkednek el. A minták üregeiben megfigyelt fenn-nőtt kalcit kristályok feltehetőleg egy későbbi karbonátképződésnek az eredményei.

A klorit, fengit és albit megjelenése alapján a zöldpala fáciesben keletkezett kőzetről van szó, amely egybevág [4] megállapításaival. A rutil, apatit és monacit a nyírási zónákban növekvő nyomás és hőmérséklet hatására kristályosodtak.

A vizsgált terület földtana [4;5], valamint észleléseink alapján a grafit szerves anyag eredetü, amely regionális metamorfózishoz kapcsolódóan, ugyancsak a nyírózónákban képződött. Erre a genetikára utal a kísérő fázisokban észlelt Th- és RFF-tartalom is.

A minták további vizsgálatát tervezzük a közeljövőben, hogy árnyaltabb képet kapjunk többek között a genetikáról és a képződési körülményekről. Tervezzük például a minták nyomelemtartalmának a meghatározását, különösen a kritikus elemekre fókuszálva, valamint a grafit, illetve ezeknek a kritikus elemeket hordozó fázisoknak a mennyiségi kiértékelését Rietveld-illesztéssel. Ezeken túlmenően a grafit kristályossági állapotáról pedig a Raman-spektroszkópia, illetve a termál analitika (szimultán DTA-TG vizsgálat) adhat információt.

\section{Köszönetnyilvánítás}

„Az Innovációs és Technológiai Minisztérium ÚNKP-20-3 kódszámú Új Nemzeti Kiválóság Programjának a Nemzeti Kutatási, Fejlesztési és Innovációs Alapból finanszírozott szakmai támogatásával készült.”

\section{Irodalom}

[1] European Commission: Study on the EU's list of Critical Raw Materials - Final Report, (2020). 10.2873/11619

[2] Holland, H. D.: Metals in black shales - a reassessment, Econ. Geol., 74 (1979) pp. 1676-1679. https://doi.org/10.2113/gsecongeo.74.7.1676 
[3] Brumsack, H. J., Lew, M.: Inorganic geochemistry of Atlantic Ocean sediments with special reference to Cretaceous black shales. In: von Rad, U., Hinz, K., Sarnthein, M., Seibold, E. (szerk.): Geology of the Northwest African Continental Margin, Springer-Verlag, New York, N.Y. (1982) pp. 661-685. https://doi.org/10.1007/978-3-642-68409-8_27

[4] Fülöp, J.: Magyarország geológiája, Paleozoikum II, Akadémiai Kiadó, Budapest, 1994.

[5] Szentpétery, I., Less, Gy. (szerk.): Az Aggtelek-Rudabányai-hegység földtana. Magyarország tájegységi térképsorozata. Magyarázó az Aggtelek-Rudabányai-hegység 1988-ban megjelent 1:25 000 méretarányú fedetlen földtani térképéhez, Magyar Állami Földtani Intézet, Budapest, 2006.

[6] Gyalog, L., Síkhegyi, F. (sorozatszerk.): Magyarország földtani térképe, M=1:100 000, A Magyar Állami Földtani Intézet kiadványa, Budapest, 2005. https://map.mbfsz.gov.hu/fdt100/

[7] Grew, E. S.: Carbonaceous material in some metamorphic rocks of New England and other areas, J. Geol., 82 (1974) pp. 50-73. https://doi.org/10.1086/627936

[8] Landis, C. A.: Graphitization of dispersed carbonaceous material in metamorphic rocks, $\begin{array}{llllll}\text { Contributions Mineralogy } & \text { Petrology, } 30 & \text { (1971) } & \text { pp. }\end{array}$ https://doi.org/10.1007/BF00373366

[9] Diessel, C. F. K., Offler, R.: Change in physical properties of coalified and graphitized phytoclasts with grade of metamorphism, Neues Jahrb. Mineral., Monatsh. H., 1(1975) pp. 1126.

[10] Wilde, S. A., Dorsett-Bain, H. L., Lennon, R. G.: Geological setting and controls on the development of graphite, sillimanite and phosphate mineralization within the Jiamusi Massif: An exotic fragment of Gondwanaland located in north-eastern China?, Gondwana Research, 2(1) (1999) pp. 21-46. https://doi.org/10.1016/S1342-937X(05)70125-8

[11] Árkai, P., Horváth, Z. A., Tóth, M.: Transitional very low- and low-grade regional metamorphism of the Paleozoic formations, Uppony Mountains, NE-Hungary: mineral assemblages, illite-crystallinity and $-b_{0}$ and vitrinite reflectance data, Acta Geologica Academiae Scientiarum Hungaricae, 24 (1981) pp. 265-294.

[12] Árkai, P.: Very low- and low-grade Alpine regional metamorphism of the Paleozoic and Mesozoic formations of the Bükkium, NE-Hungary, Acta Geologica Hungarica, 26 (1-2) (1983) pp. 83-101.

[13] Árkai, P., Balogh, K., Dunkl, I.: Timing of low-temperature metamorphism and cooling of the Paleozoic and Mesozoic formations of the Bükkium, innermost Western Carpathians, Hungary, Geologische Rundschau, 84 (1995) pp. 334-344. https://doi.org/10.1007/s005310050009

[14] Oalmann, J. A. G., Barnes, C. G., Hetherington, C. J.: Geology of the island of Ylvingen, Nordland, Norway: Evidence for pre-Scandian ( 475 Ma) exhumation in the Helgeland Nappe Complex, Norsk Geologisk Tidsskrift, 91 (2011) pp. 77-99.

[15] Luvizotto, G. L., Zack, T., Triebold, S., von Eynatten, H.: Rutile occurrence and trace element behavior in medium-grade metasedimentary rocks: example from the Erzgebirge, Germany, Miner Petrol, 97 (2009), pp 233-249. https://doi.org/10.1007/s00710-009-0092-z

[16] Finger, F., Krenn, E.: Three metamorphic monazite generations in a high-pressure rock from the Bohemian Massif and the potentially important role of apatite in stimulating polyphase monazite growth along a PT loop, Lithos, 95 (2007) pp. 103-115. https://doi.org/10.1016/j.lithos.2006.06.003 